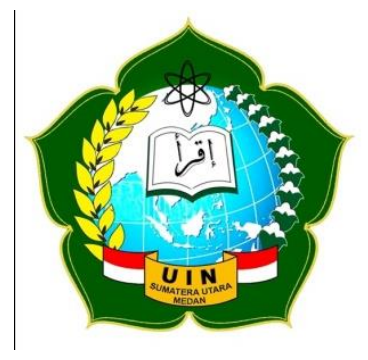

VISION JOURNAL

http://jurnaltarbiyah.uinsu.ac.id/vision

E-ISSN 2745-7982

\title{
THE EFFECT OF WEBBING STRATEGY TO IMPROVE THE STUDENTS' READING COMPREHENSION
}

\author{
Dea Azlina \\ Email: dea.azlina@uinsu.ac.id \\ Department of English Education, State Islamic University of North Sumatera
}

\begin{tabular}{|c|c|}
\hline Keywords & Abstract \\
\hline $\begin{array}{l}\text { Keywords: Webbing Strategy, } \\
\text { Students'Reading } \\
\text { Comprehension }\end{array}$ & $\begin{array}{l}\text { This study was conducted to find out the effect of using } \\
\text { webbing strategy on the students' reading comprehension. } \\
\text { The objective of the study was to find out whether any } \\
\text { significant effect of using webbing strategy on the students' } \\
\text { reading comprehension at the tenth grade of MAS } \\
\text { Muhammadiyah Sei Apung Jaya. The method of this research } \\
\text { was quantitatitave research. This quantitative research used } \\
\text { quasi-experimental design. The population of the study was } \\
\text { the tenth grade of MAS Muhammadiyah Sei Apung Jaya } \\
\text { which consisted of } 56 \text { students. While, the sample of this } \\
\text { research was consisted of experimental group and controlled } \\
\text { group, each group consisted of } 28 \text { students. The experimental } \\
\text { group taught by using webbing strategy, while the controlled } \\
\text { group without webbing strategy. The instrument of collecting } \\
\text { data was tests (pre-test and post-test) and doccumentation. } \\
\text { The data were analysed used preliminary tests and T-test. In } \\
\text { conclusion, webbing strategy can give significant effect on } \\
\text { students' improvement in reading comprehension. The mean } \\
\text { score of post-test in experimental group is } 88,03 \text {, meanwhile } \\
\text { the mean score of post-test in controlled group is } 62,86 \text {. } \\
\text { Beside that, the significant effect can be seen in the hypothesis } \\
\text { test, which Tobserved is higher than Ttable, ( } 9,186>1,673 \text { ) in the } \\
\text { level of degree } \alpha \text { is in significant } 0,05 \text {. It means that there was } \\
\text { significant effect of using webbing strategy to improve } \\
\text { students' reading somprehension at the Tenth grade of MAS } \\
\text { Muhammadiyah Sei Apung Jaya. }\end{array}$ \\
\hline
\end{tabular}

Faculty of Tarbiyah and Teacher Training, 1st Floor

Jalan Willem Iskandar Psr V Medan, 20731

Telp. 061- 6622925 - Fax. 061 - 6615685 


\section{INTRODUCTION}

There are four basic but important skills that must be learned if we would like to master English, they are speaking, writing, listening and reading. Every skill has its own specification, include reading skill. Broek and Espin (2012) stated that Reading comprehension is a complex interaction among automatic and strategic cognitive processes that enables the reader to create a mental representation of the text. Rather than only understand about acquire meaning, but also to understanding the text deeply such as identifying main idea, supporting ideas, finding reference, making inference, and answering the question that relates with the text, etc. Through reading, it is not only increase insightful and knowledge but also can gain strength imagination and spiritual experience through the text that have been read.

Helena (2014) showed that Indonesia is one of the countries which has poor reading qualities. The poor reading quality can effect to shape understanding from reading material. The poor reading quality is caused by the lack of reading habit in life. It is because reading is not become important activity in school or education institution. Besides, reading plays important role in language learning.

The objectives of teaching English subject for senior high school level is the students are able to express their idea, feeling, and information well, that is why teaching english as a subject in school is not easy as teaching first language or national language.

In reality, the objective of reading comprehension as mentioned above is not fully achieved yet. All the objectives about reading comprehension that we expected to be mastered by the students are not totally gained. It can be seen from what Helena stated about Indonesia's reading quality that effected to students' readingcomprehension. It also can be seen from what researcher found in reality. Based on the first observation in MAS Muhammadiyah Sei Apung Jaya, approximately all of the students have problem in reading comprehension. First, there are some of the students hard to link the ideas of the text. Second, the studentswere hard to answer question related to text because they faced difficulties in getting main idea of the text.

After the researcher analysed some of the students' reading comprehension difficulties by asking the students. Then, researcher analysed teaching reading activity. The researcher found there are some causes can be described regarding to the factors why students' reading comprehension low. First, reader's ability in reading process that caused by internal factor, such as motivation, IQ (Intelligence Quotient), etc. Second, the teacher only asked the students to read the text and look up for difficult words in dictionary, the teacher 
didn't guide the students how to get the meaning of the word related to the contextual situation. Third, the teacher taught the students to understand the reading material monotonously. Teacher did not facilitate the students with the certain strategy to find out the meaning contextually and to comprehend the reading material deeply.

For that reason, the researcher tried to apply new strategy in teaching reading comprehension to find out the whether is it effective or not to improve students' reading comprehension, especially in MAS Muhammadiyah Sei Apung Jaya. So, the researcher carried out this research to help the teacher of MAS Muhammadiyah Sei Apung Jaya to overcome the students' difficulties in reading comprehension.

\section{LITERATURE REVIEW}

\section{Reading as a Language Skill}

According to Brown (1994), there are four language skills in English that should be mastered. They are listening, speaking, reading, and writing. Reading is one of essential skills for second language learners. Reading is the basic skill in language learning that everyone should have. Reading is the key of knowledge because the biggest source of knowledge is written form. There are many definition about reading given by experts. Martin (1991) stated that reading is the activity of looking at and understanding written words. It means that reading process can be done if someone do the reading activity by looking at reading material and understand the content of it.

According to Patel (2008), reading means to understand the meaning of printed word i.e written symbols. From what Patel stated, reading means the activity of the reader finds out and understand the message or information from what writer put in the text. The writer as informant (sender) who sends the message or information to readers (receiver) through text or written symbols. From those definitions can be concluded that reading is an activity of someone tries to get information through written forms in case to catch what the writer means or says.

Richard, Platt and Weber (1985) stated that reading Comprehension has some types, they are; 1) Literal comprehension: reading in order understand, remember, or recall the information explicitly contained in passage. 2) Inferential comprehension: reading in order to find information which is not explicitly stated in passage, using the reader ${ }^{\text {re }} \mathrm{s}$ experience and intuition, and by inferring. 3) Critical/evaluative comprehension: reading in order to compare information in a passage with the reader"s own knowledge and value. 4) Appreciative 
comprehension: reading in order o gain an emotional or the kind of valued response from passage.

\section{Kinds of reading}

Intensive reading.

According to Harmer (2007), intensive reading means to read shorter texts to extract specific information. In this type of reading, readers focus on linguistics feature and semantic feature of the text. There are two types of intensive reading, they are:

1) Reading Aloud. It means read with sound. In reading aloud, the students will get experience in producing the sound, which should be practiced as many as possible.

2) Reading Fast. Reading fast used to improve speed and comprehension in reading. Sometimes this kind of reading is just to find main idea or reference that do not need deeper understanding about the whole meaning of the text.

\section{Extensive Reading}

Harmer (2001) stated that extensive reading is usually reading activity in a longer text. Extensive reading is also to obtain a general understanding of a subject and include reading longer text for pleasure use extensive reading is to improve general knowledge. Patel and Jain (2008) stated that the purpose of extensive reading will be to train the students to read directly and fluently in the target language for enjoyment, without the aid of the teacher. A type of extensive reading, it is silent reading. It means reading without producing sound. Sometimes whispering what they read, but sometimes don't make any sound regarding to understand the text. Patel and Jain (2008) also stated that silent reading is done to acquire a lot of information.

\section{Webbing as a Strategy of Teaching Reading Comprehension}

J. W. Gillet (1986) noted Webbing is a simple way to help students begin to recall prior knowledge and form relationship is to use webbing. Webbing strategy is one of suggested strategies from experts if the teacher would like to teach reading. Because the webbing can help the students build their thinking about organizing ideas and information from a topic. Webbing also can help the students to remember old 
information related to the reading material and help students create expectation from their perception about what they read.

\section{The Procedure of Webbing Strategy}

Denton, et.al (2007: 115) suggest the teacher to implement the procedures of webbing strategy in helping students to do comprehending on reading stages. These reading stages are:

1. Pre-reading that includes activities as showing the webbing strategy to students and discuss students' prior knowledge, using the webbing strategy as a tool to preview the chapter or text, and asking students to make predictions about the text based on the graphic organizer or ovals. Therefore, in the pre-reading, the activities are focused on the students' vocabulary and background or prior knowledge through questioning and some ovals or webbing;

2. During-reading that includes activities as having students fill in important information as they read the text, and conforming and/or modify students' predictions about the text. In this stage, the activities are focused on grasping and extracting the topics, explicit and implicit information;

3. Post-reading that includes activities as having students write a summary of the chapter or text using the webbing strategy as a guide, having students use the webbing strategy to present the content orally to a peer, tutor, or mentor, and having students write guide or test questions based on the webbing strategy.

\section{RESEARCH METHODOLOGY}

\section{Research Design}

The researcher conducted the research using quasi-experimental design. Quasiexperimental design involved subject as a group (intact groups). There will be two groups in this research, they are experimental group and controlled group. The population of this research is the tenth grade of MAS Muhammadiyah Sei Apung Jaya 2020/2021. It consists 2 classes. The grade X MIA-1 consists of 28 students. The grade X MIA-2 consists of 28 students.

\section{Population and Sample}

This research held in MAS Muhammadiyah Sei Apung Jaya. The location in Jln. Raya Bagan Asahan, Sei Apung Jaya Village, Kec. Tanjung Balai, Kab. Asahan, North 
Sumatera. According to Ary (2010), population is all of members of any well defined class of people, events, or object. The population of this research is the tenth grade of MAS Muhammadiyah Sei Apung Jaya 2020/2021. It consists 2 classes. The grade X MIA-1 consists of 28 students. The sample for experimental group is 28 students, consisted of 13 males and 15 females. For controlled group there are 28 students as well, 12 students males and 16 females.

\section{Research Instrument}

According to Arikunto (2006), research instrument refers to any equipment used to collect the data. To measure the students' achievement, the researcher prepares the test. The test in this research is pre-test and post-test. Djaali, Muljono and Sudarmanto (2008) stated that pre-test is the initial test aims to know how far the learning material to be taught is known by the students. The post-test is used to collect the data from the students about how far successfulness teaching learning process using webbing strategy.

\section{Data Analysis}

The purpose of this analysis is to know whether the data is accepted or not as requirement for t-test and hypothesis test. Before T-test is used, the normality and homogenity data should be tested. The calculation of normality test is using Microsoft Excel 2010. Homogeneity test samples originated from populations that were homogenous. This test used statistical formulation of homogeneity test by using two variants in pre-test and post-test.

\section{FINDING AND DISCUSSION}

The data were analysed based on students' score in pre-test and post test. The score analysis will be shown in this table below :

Table 1. Descriptive Statistics

\begin{tabular}{||l|c|c|c|c|c|}
\hline & N & Min & Max & Mean & $\begin{array}{c}\text { Standart } \\
\text { deviation }\end{array}$ \\
\hline \hline Pre-test Experimental group & 28 & 20 & 60 & 41,97 & 11,4939 \\
\hline Post-test Experimental Group & 28 & 70 & 100 & 88,03 & 9,6550 \\
\hline Pre-test Controlled Group & 28 & 15 & 60 & 36,25 & 11,0239 \\
\hline Post-test Controlled Group & 28 & 40 & 80 & 62,86 & 10,8379 \\
\hline Valid N & 28 & & & & \\
\hline
\end{tabular}


There is significant effect of using webbing strategy to improve students' reading somprehension at the tenth grade of MAS Muhammadiyah Sei Apung Jaya. It can be seen that the students who were tought using webbing strategy gained much higher score than the students who were tought without webbing strategy.

Figure 1. Score of Pre-test

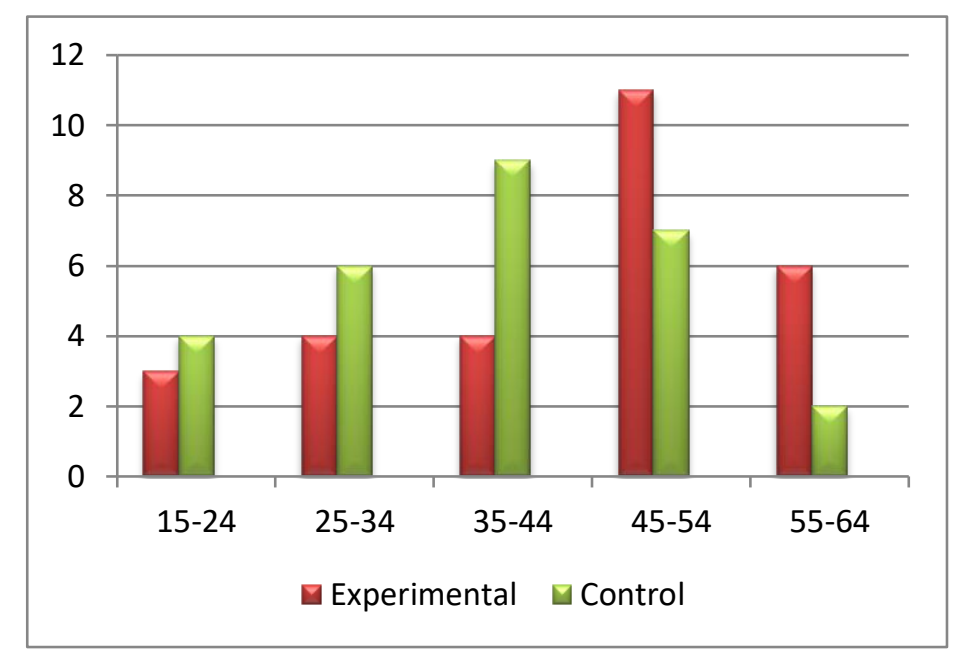

Figure 1 shows that the experimental group and controlled group have same range score in pre-test. The range of the score in experimental group and controlled group is around 15-64. It can be meant that the lowest and the highest score of pre-test in experimental group and controlled group are quite simillar, but these two groups have different number of the students in each range of the score. Based on the result, the gap of pre-test of both groups is not so huge. It means that the students in both group have same level of knowledge in reading comprehension.

Figure 2 Score of Post-test

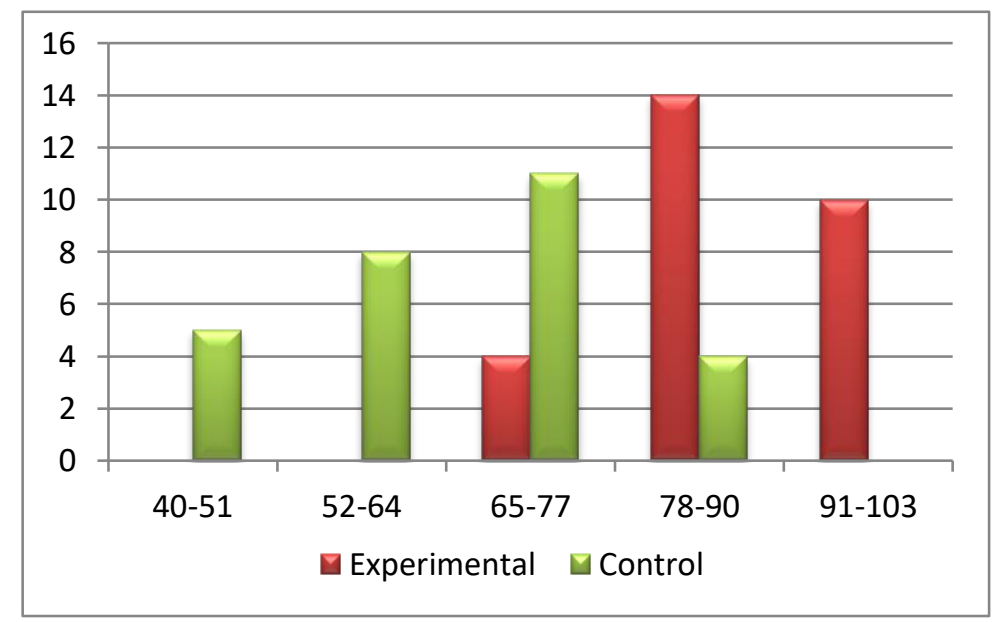


Based on the figure 4.2 above, these two groups, experimental group and controlled group have difference in range of score. We can see the range of lowest and highest score is different. It can be seen in the figure above that there is a huge gap number of students in the range 78-90. In this range, the number of students of experimental group is around 14 students, meanwhile the number of the students of controlled group in this range is around 4 students. In this range becomes the highest number of students who get the score in experimental group. The range of score 65-77 becomes the highest number of students who get the score in controlled group. There are 11 students obtained the score in this range.

The calculation of T-test as follows :

$$
\begin{aligned}
& \mathrm{T}=\frac{\bar{X}_{1}-\bar{X}_{2}}{\sqrt{\frac{s_{1}{ }^{2}}{n 1}+\frac{s_{2}{ }^{2}}{n 2}}} \\
& \mathrm{~T}=\frac{88,03-62,86}{\sqrt{\frac{93,22}{28}+\frac{117,46}{28}}} \\
& \mathrm{~T}=\frac{25,17}{\sqrt{\frac{210,68}{28}}} \\
& \mathrm{~T}=\frac{25,17}{\sqrt{210,68}} \\
& \mathrm{~T}=\frac{25,17}{2,74}=\mathbf{9 , 1 8 6}
\end{aligned}
$$

Based on the T-test calculation above, it shows the result of $t$ observation is around 9,186. From this testing, the calculation of $\mathrm{T}_{\text {table }}$ with the degree of freedom $56\left(\mathrm{df}=\mathrm{N}_{1}+\mathrm{N}_{2}-\right.$ 2) $(\mathrm{df}=(28+28)-2)$ and at the level of significant 0,05 in $T_{\text {table }}$ is 1,673 . From that testing calculation, it can be concluded that $\mathrm{T}_{\mathrm{o}}$ is higher than $\mathrm{T}_{\text {table }}(9,186>1,673)$. It means that there is significant effect of using webbing strategy to improve students' reading somprehension at the tenth grade of MAS Muhammadiyah Sei Apung Jaya.

This strategy is one of suggested strategies in teaching reading comprehension. This strategy is expected to help student to find the meaning of the vocabulary regarding to comprehend the reading material easily, also can help students to find sollution to increase students' reading achievement. Webbing strategy can be used to help students to create background knowledge about the reading material, also to help students to link among 
vocabulary terms in the reading material by connecting new information to prior knowledge. These were some considerations from the advantages of webbing strategy in the learning reading comprehension.

\section{CONCLUSION}

Based on the research finding and discussion in this study, it can be concluded that webbing strategy can give significant effect on the students' reading comprehension at the tenth grade of MAS Muhammadiyah Sei Apung Jaya. The effect of the result in this research is not only supported by the researcher, but it is also supported by several things. One of them is the students' enthusiasm. During the teaching and learning process, the students gave so much attention to the material given. The students were actively involved in the teaching and learning process so that the students' got many benefit from the treatment. For the students, This strategy is quite easy to use. This strategy can be used individually not only in school but also in home when doing their homeworks. For the English teachers. It is become one of teacher duties to use various strategies in teaching English, not only fun strategy but suitable strategy. Webbing strategy is one of the suggested strategies by expert that can help to improve students' reading comprehension.

\section{REFERENCE}

Arikunto, Suharsimi. (2006). Prosedur Penelitian Suatu Pendekatan Praktek. Jakarta: Rineka Cipta.

Ary, Donald., Lucy Cheser Jacobs, and Chris Sorensen. (2010). Introduction To Research in Education. Canada: Wadsworth Cengange Learning.

Brown, H. Douglas. (1994). Teaching by Principles: An Interactive Approach to Language Pedagogy. New Jersey : Prentice Hall Regents.

Ceranic, Helena. (2014). Panduan Bagi Guru Bahasa Inggris. Jakarta: Erlangga.

Denton, C. Bryan, D. Wexler, J. Reed, D. \& Vaughn, S. (2007). Effective Instruction for Middle School Students with Reading Difficulties. (https://teachingenglish4all.wordpress.com/, accessed on September 22, 2020)

Djaali, Pudji Muljono and Sudarmanto. (2008). Pengukuran dalam Bidang Pendidikan. Jakarta: Grasindo.

Harmer, Jeremy. (2001). The Prectice of English Language Teaching Longman Handbooks for Language Teacher. London : Longman Eight.

Harmer, Jeremy. (2007). How to Teach English, Harlow: Longman Pearson. 
Larry, Harris A and Smith B Carl. (1986). Understanding Reading Problems Assessment and Instruction. New York: Macmillan.

Manser, Martin H. Oxford Learner's Pocket Dictionary. Oxford: Oxford University Press.

Patel, M.F. (2008). English Language Teaching, (Methods, Tools, and Techniques). Jaipur: Sunrise publishers.

Richard, Jack., Jhon Platt and Heidi Weber. (1986). Longman Dictionary of Applied Linguistic. RELC Journal. Vol 17(2)

Van den Broek, P., \& Espin, C. A. (2012). Connecting cognitive theory and assessment: Measuring individual differences in reading comprehension. School Psychology Review, Vol 41(3) 